Joseph Academy in Vienna, where he succeeded Duchek as director of the medical clinic in 1871 . $\mathrm{He}$ held that office until 1874 when he became head of a medical department in the Garrison Hospital, Vienna, and remained there until his death on November 16, 1884. His literary activity is shown by the fact that during the last twenty years of his life he published no less than 163 articles on various medical subjects. Although he specialised in electrotherapy, he published only six papers on the use and value of electricity in medicine, most of his writings being concerned with the pathology and treatment of diseases of the nervous system. His name is attached to a sign consisting in the sudden spasm seen on tapping one side of the face.

\section{Excavations at Colchester}

THE preliminary survey, anticipatory to complete publication, of the results of five years excavation on the Romano-British site at Colchester, which Mr. Christopher Hawkes contributed to The Times of April 12, by bringing together the more significant of the details already reported in the accounts of current progress, gives a clearer conception than has previously been possible of the extent to which this investigation has added to our knowledge of conditions in south-eastern Britain immediately before, and in the early days of Roman conquest. The magnificent system of fortification which has been revealed, in its relation to the occupation site which it defends, bears eloquent testimony to the high degree of organisation and the social and political importance attained by this British town; while the character of the finds, especially the local factory of Samian ware, a feature without known parallel in Britain, indicates, on one side its importance as a centre of British culture, and on the other its standing as a point of close economic, and probably political, relation with the Continent. Although it has been possible to follow the course of events on the area of British occupation and its history in later days in some detail, the position still remains somewhat obscure. It would appear as if still more important discoveries have yet to be made. Nothing that appeals as adequate to the dignity of this centre of the Belgic settlers has as yet been discovered. It is all the more important, therefore, that means should not be lacking to follow up the investigation before the commercial development of the area precludes further excavation. The appeal of the Colchester Excavation Committee for further funds deserves, and should receive, generous support.

\section{Unveiling of the Replica of the Rocket Locomotive}

ON April 11, the Minister of Transport, Mr. L. Hore-Belisha, unveiled the new replica of the Rocket which has just been added to the locomotive collection in the Science Museum, South Kensington. Mr. Hore-Belisha pointed out that the importance of the Rocket in the history of the locomotive lies in the fact that the chief features of its design had been followed down to the present day. He then referred to the precautions for the public safety which have been taken from the earliest days of the railway, so that the numerous regulations which govern the movement of traffic on rails are not regarded as restrictions, but as guarantees of efficiency and security. Had similar foresight been shown in connexion with the motor-car, the nation might have been spared the material, economic and personal loss which the weekly casualty lists reveal. We are now trying to make good rapidly the omissions of forty years. The measures we are now forced to institute, had they proceeded pari passu with the growth in the numbers of mechanically propelled vehicles on the road, would have been regarded as natural. Methods of road traffic control are being borrowed from the railway. The Rocket demonstrated its capacity in a competition on the railway. To-day, it would probably have been sent to the testing station at Vitry, in France, to enable its operation to be scientifically studied. In the country which produced the Rocket, there is no similar testing station for locomotives, and Mr. Hore-Belisha expressed the hope that the omission would be repaired.

\section{Liverpool Naturalists' Field Club}

ON April 27 the Liverpool Naturalists' Field Club celebrates the seventy-fifth anniversary of its founda. tion by a field meeting at Rabymere, Cheshire, where its first meeting was held in 1860. The Club has been responsible for three floras of Liverpool, one the work of Mr. Robert Brown, who also wrote the botanical section to the British Association Liverpool Handbook, and the last two the works of Col. C. T. Green. Founded by the Rev. H. H. Higgins (president 1862-93) and Dr. Joseph Dickinson (president 186062) the Club has maintained an active and amiable co-operation between professional scientific workers and amateurs in all branches of field natural history, and at present has referees in botany (W. S. Laverock), micro-fungi (Dr. C. T. Green), aquaria (Fred Jefferies), lepidoptera (Mrs. Makinson) and ornithology (Eric Hardy), the ornithological section having plans to form a local bird observatory or ringing station like that at Heligoland, as a mark of the anniversary. Some of the leading members in the Club's history were: Rev. H. H. Higgins, who discovered 200 additions to the local flora in four years, and was author of works on the fungi, Diptera, flora and other subjects of the Liverpool district, and particularly the notable collection of fern fossils he discovered at Ravenhead, Lancashire ; G. H. Morton (president 1894), who delivered an address to the Club on the geology of Liverpool which the council published and which was later enlarged into his celebrated "Geology of Liverpool"; Col. J. W. Ellis (president 1899 and 1910) and Prof. Robert Newstead (president 1907-8), entomologists; and Dr. Joseph Dickinson, author of the second "Flora of Liverpool". Since its foundation, the Club has not failed to issue an annual proceedings of 40-50 pages, and at one time its members issued their own monthly journal, the Liverpool Naturalists' Scrap Book, followed by the Liverpool Naturalists' Journal. The honorary secretary is Mrs. W. S. Laverock, Millbank, Mill Lane, Wallasey. 